\title{
Correction to: ranking major and minor research misbehaviors: results from a survey among participants of four World Conferences on Research Integrity
}

\author{
Lex M. Bouter ${ }^{1,2^{*}}$, Joeri Tijdink ${ }^{2,3}$, Nils Axelsen ${ }^{4}$, Brian C. Martinson ${ }^{5}$ and Gerben ter Riet ${ }^{6}$
}

Correction to: Research Integrity and Peer Review (2016) 1:17

https://doi.org/10.1186/s41073-016-0024-5

Following publication of the original article [1], the authors reported that an incorrect version of Table 4.1 in Additional 4 has been published. A corrected version of Additional file 4 is attached to this Correction.

\section{Additional file}

Additional file 4: Rankings of major and minor research misbehaviors. (PDF $78 \mathrm{~kb}$ )

\begin{abstract}
Author details
'Department of Epidemiology and Biostatistics, VU University Medical Center, Amsterdam, The Netherlands. ${ }^{2}$ Department of Philosophy, Faculty of Humanities, Vrije Universiteit, Amsterdam, The Netherlands. ${ }^{3}$ Department of Internal Medicine, VU University Medical Center, Amsterdam, The Netherlands. ${ }^{4}$ Office of Research Integrity, Statens Serum Institut, Copenhagen, Denmark. ${ }^{5}$ Department of Medicine, HealthPartners Institute and Minneapolis Veterans Affairs, Center for Chronic Disease Outcomes Research and University of Minnesota, Minneapolis, MN, USA. ${ }^{6}$ Department of General Practice, Academic Medical Center, University of Amsterdam, Amsterdam, The Netherlands.
\end{abstract}

Received: 29 May 2019 Accepted: 29 May 2019

Published online: 28 June 2019

\section{Reference}

1. Bouter $L M$, et al. Ranking major and minor research misbehaviors: results from a survey among participants of four world conferences on research integrity. Res Integrity Peer Rev. 2016;1:17 https://doi.org/10.1186/s41073016-0024-5.

\footnotetext{
* Correspondence: Im.bouter@vu.nl

'Department of Epidemiology and Biostatistics, VU University Medical Center, Amsterdam, The Netherlands

${ }^{2}$ Department of Philosophy, Faculty of Humanities, Vrije Universiteit,

Amsterdam, The Netherlands

Full list of author information is available at the end of the article
}

(c) The Author(s). 2019 Open Access This article is distributed under the terms of the Creative Commons Attribution 4.0 International License (http://creativecommons.org/licenses/by/4.0/), which permits unrestricted use, distribution, and reproduction in any medium, provided you give appropriate credit to the original author(s) and the source, provide a link to the Creative Commons license, and indicate if changes were made. The Creative Commons Public Domain Dedication waiver (http://creativecommons.org/publicdomain/zero/1.0/) applies to the data made available in this article, unless otherwise stated. 